\title{
Effective targeted chemotherapy using AEZS-108 (AN-152) for LHRH receptor-positive pancreatic cancers
}

\author{
CARSTEN GRÜNDKER ${ }^{1}$, JENNIFER ERNST ${ }^{1}$, MADITA D. REUTTER ${ }^{1}$, \\ B. MICHAEL GHADIMI ${ }^{2}$ and GÜNTER EMONS ${ }^{1}$ \\ Departments of ${ }^{1}$ Gynecology and Obstetrics, and ${ }^{2}$ General and Visceral Surgery, \\ Georg-August University, Göttingen 37075, Germany
}

Received April 27, 2011; Accepted May 20, 2011

DOI: $10.3892 /$ or.2011.1340

\begin{abstract}
Pancreatic cancer is the fourth commonest cause of cancer-related mortality across the world. Because of the poor response to conventional chemotherapy, small molecules, radiation therapy and surgery, development of new targeted therapies is necessary. In the present study, we have analyzed expression of the luteinizing hormone releasing hormone (LHRH) receptor in specimens of human pancreatic cancers. Furthermore, we have investigated in vitro and in vivo whether the cytotoxic LHRH agonist AEZS-108 (AN-152) induces apoptosis in human pancreatic cancer cells that express LHRH receptors. LHRH receptor expression in tumor specimens of human pancreatic cancers was assessed using immunohistochemistry. Cell proliferation was analyzed using the Alamar Blue proliferation assay. Induction of apoptosis was analyzed using the TUNEL assay and quantified by measurement of loss of mitochondrial membrane potential. In vivo experiments were performed using nude mice bearing xenografted human pancreatic tumors. Thirteen of 40 human pancreatic adenocarcinomas (32.5\%) expressed LHRH receptors. We were able to show that treatment of LHRH receptor-positive MiaPaCa-2 and Panc-1 human pancreatic cancer cells with AEZS-108 (AN-152) resulted in apoptotic cell death in vitro. The antitumor effects could be confirmed in nude mice. AEZS-108 (AN-152) inhibited the growth of xenotransplants of human pancreatic cancers in nude mice significantly, without any apparent side effects. The cytotoxic LHRH agonist AEZS-108 (AN-152) seems to be a suitable drug for treatment of LHRH receptor-positive human pancreatic cancers with little toxicity.
\end{abstract}

\section{Introduction}

The survival rate of patients with any stage of pancreatic cancer is poor. Pancreatic cancer spreads rapidly and is

Correspondence to: Dr Carsten Gründker, Department of Gynecology and Obstetrics, Georg-August University, Robert Koch Street 40, Göttingen 37075, Germany

E-mail: grundker@med.uni-goettingen.de

Key words: AEZS-108, luteinizing hormone releasing hormone receptor, targeted therapy, pancreatic cancer seldom detected in its early stages, which is a major reason why it is a leading cause of cancer death $(1,2)$. Signs and symptoms of pancreatic cancer often do not occur until the disease is advanced. No specific tumor marker for the diagnosis of pancreatic cancer exists (3). Pancreatic cancer is relatively resistant to conventional chemotherapeutic agents due to primary or secondary chemoresistance $(4,5)$. Because of the poor response to conventional chemotherapy, small molecules, enzyme inhibitors, radiation therapy, and surgery, development of new targeted therapies is necessary. Some reports assume that pancreatic cancers express receptors for luteinizing hormone releasing hormone (LHRH, GnRH) (6-8). Therefore, we considered that a therapy using LHRH receptors as a target may be applicable for LHRH receptorpositive pancreatic cancers.

The expression of LHRH and its receptor as a part of a negative autocrine/paracrine regulatory mechanism of cell proliferation has been demonstrated in a number of malignant tumors, including cancers of the endometrium, ovary and breast (9). The LHRH receptor could be used for targeted chemotherapy to improve antitumor effects, reduce side effects compared with conventional systemic chemotherapy and to escape chemoresistance mechanisms of the tumors. LHRH agonists that are covalently linked to cytotoxic compounds bind specifically to LHRH receptors with their peptide moiety and act as chemotherapeutic agents after internalization of the ligand-receptor complex (10). Thus, these conjugates selectively affect those cells that express LHRH receptors and exert fewer side effects than unconjugated cytotoxic agents. In addition, by entering the tumor cell via a receptor-mediated internalization, resistance mechanisms like multidrug resistance-1 (MDR-1) are circumvented $(11,12$ ). LHRH agonists that have a D-Lys moiety at position 6 offer an amino side chain for a convenient attachment of various cytotoxic compounds. Even bulky molecules can be linked to the $\varepsilon$-amino group of the D-Lys ${ }^{6}$ moiety without a significant loss of binding affinity of the peptide portion to the receptors for LHRH (10). We were able to demonstrate that such a cytotoxic LHRH analogue, AEZS-108 (AN-152), in which doxorubicin is linked to the agonist carrier [D-Lys ${ }^{6}$ ]LHRH, is selectively internalized in human ovarian, endometrial and breast cancer cell lines that express LHRH receptors. After internalization of AEZS-108 (AN-152), doxorubicin is 
Table I. LHRH receptor expression in human pancreatic adenocarcinoma specimens.

\begin{tabular}{|c|c|c|c|c|c|c|c|}
\hline No. & Gender & Age & Pathology diagnosis & Grade & Stage & TNM & LHRH R \\
\hline 1 & Male & 65 & Adenocarcinoma & 2 & III & T3N1M0 & NO \\
\hline 2 & Male & 52 & Adenocarcinoma & 1 & III & T3N1M0 & YES \\
\hline 3 & Female & 45 & Adenocarcinoma & 2 & III & T3N1M0 & NO \\
\hline 4 & Male & 44 & Adenocarcinoma & 2 & II & T3NOM0 & $\mathrm{NO}$ \\
\hline 5 & Male & 47 & Adenocarcinoma (sparse) & 1 & II & T3N0M0 & NO \\
\hline 6 & Male & 55 & Adenocarcinoma & 2 & II & T3N0M0 & YES \\
\hline 7 & Male & 57 & Adenocarcinoma (sparse) with necrosis & 2 & II & T3N0M0 & NO \\
\hline 8 & Male & 34 & Adenocarcinoma & 1 & II & T3NOM0 & YES \\
\hline 9 & Female & 56 & Adenocarcinoma & 1 & III & T3N1M0 & NO \\
\hline 10 & Male & 42 & Adenocarcinoma & 1 & IV & T2N0M1 & YES \\
\hline 11 & Female & 39 & Adenocarcinoma & 2 & II & T3N0M0 & YES \\
\hline 12 & Male & 44 & Adenocarcinoma & 2 & II & T3NOM0 & $\mathrm{NO}$ \\
\hline 13 & Male & 59 & Adenocarcinoma & 2 & II & T3N0M0 & NO \\
\hline 14 & Male & 65 & Adenocarcinoma (fibrofatty tissue) & - & II & T3N0M0 & NO \\
\hline 15 & Female & 67 & $\begin{array}{l}\text { Adenocarcinoma } \\
\text { (chronic inflammation of pancreas tissue) }\end{array}$ & - & II & T3NOM0 & NO \\
\hline 16 & Male & 53 & Adenocarcinoma & 1 & II & T3N0M0 & YES \\
\hline 17 & Male & 52 & Adenocarcinoma & 2 & II & T3N0M0 & NO \\
\hline 18 & Female & 72 & Adenocarcinoma & 1 & II & T3N0M0 & NO \\
\hline 19 & Female & 58 & Adenocarcinoma & 2 & II & T3N0M0 & YES \\
\hline 20 & Male & 41 & Adenocarcinoma & 2 & II & T3N0M0 & NO \\
\hline 21 & Male & 51 & Adenocarcinoma & 2 & II & T3N0M0 & YES \\
\hline 22 & Male & 41 & Adenocarcinoma (sparse) & - & II & T3N0M0 & NO \\
\hline 23 & Female & 68 & Adenocarcinoma & 2 & II & T3N0M0 & NO \\
\hline 24 & Female & 41 & Adenocarcinoma & 2 & II & T3N0M0 & NO \\
\hline 25 & Female & 72 & Adenocarcinoma & 2 & II & T3N0M0 & YES \\
\hline 26 & Female & 76 & Adenocarcinoma with necrosis & 2 & III & T4N0M0 & YES \\
\hline 27 & Male & 52 & Adenocarcinoma & 2 & II & T3N0M0 & NO \\
\hline 28 & Female & 60 & Adenocarcinoma & 2 & III & T4N0M0 & NO \\
\hline 29 & Male & 76 & Adenocarcinoma (sparse) & 2 & II & T3N0M0 & NO \\
\hline 30 & Male & 78 & Adenocarcinoma & 2 & II & T3N0M0 & NO \\
\hline 31 & Male & 41 & Adenocarcinoma & 2 & III & T4N1M0 & NO \\
\hline 32 & Female & 62 & Adenocarcinoma & 3 & II & T3N0M0 & NO \\
\hline 33 & Male & 51 & Adenocarcinoma (sparse) & - & II & T3N0M0 & NO \\
\hline 34 & Male & 50 & Adenocarcinoma & 3 & III & T3N1bM0 & YES \\
\hline 35 & Male & 60 & Adenocarcinoma & 2 & III & T3N1M0 & NO \\
\hline 36 & Female & 53 & Adenocarcinoma & 2 & II & T3N0M0 & NO \\
\hline 37 & Male & 59 & Adenocarcinoma & 2 & II & T3N0M0 & NO \\
\hline 38 & Male & 56 & Adenocarcinoma & 3 & III & $\mathrm{T} 2 \mathrm{~N} 1 \mathrm{bM} 0$ & YES \\
\hline 39 & Female & 60 & Adenocarcinoma & 3 & IV & T2N1M1 & YES \\
\hline 40 & Female & 66 & $\begin{array}{l}\text { Adenocarcinoma } \\
\text { (fibrous tissue and blood vessel) }\end{array}$ & - & II & T3N0M0 & NO \\
\hline 41 & Male & 40 & Normal pancreas tissue & - & - & - & NO \\
\hline 42 & Male & 47 & Normal pancreas tissue & - & - & - & NO \\
\hline 43 & Male & 25 & Normal pancreas tissue & - & - & - & NO \\
\hline 44 & Female & 35 & Normal pancreas tissue & - & - & - & NO \\
\hline 45 & Male & 30 & Normal pancreas tissue & - & - & - & NO \\
\hline 46 & Male & 50 & Normal pancreas tissue & - & - & - & NO \\
\hline
\end{tabular}


Table I. Continued.

\begin{tabular}{|c|c|c|c|c|c|c|c|}
\hline No. & Gender & Age & Pathology diagnosis & Grade & Stage & TNM & LHRH R \\
\hline 47 & Male & 30 & Normal pancreas tissue & - & - & - & $\mathrm{NO}$ \\
\hline 48 & Male & 40 & Normal pancreas tissue & - & - & - & $\mathrm{NO}$ \\
\hline 49 & Male & 35 & Normal pancreas tissue & - & - & - & NO \\
\hline 50 & Female & 21 & Normal pancreas tissue & - & - & - & NO \\
\hline
\end{tabular}

Grade 1 or well-differentiated, cells appear normal and are not growing rapidly. Grade 2 or moderately-differentiated, cells appear slightly different than normal. Grade 3 or poorly differentiated, cells appear abnormal and tend to grow and spread more aggressively. TNM grading: Tx, primary tumor cannot be assessed; T0, no evidence of primary tumor; Tis, carcinoma in situ; intraepithelial or invasion of lamina propria; $\mathrm{T} 1$, tumor invades submucosa; T2, tumor invades muscularis propria; $\mathrm{T} 3$, tumor invades through muscularis propria into subserosa or into non-peritonealized pericolic or perirectal tissues; T4, tumor directly invades other organs or structures and/or perforates visceral peritoneum. $\mathrm{Nx}$, regional lymph nodes cannot be assessed; N0, no regional lymph node metastasis; N1, metastasis in 1 to 3 regional lymph nodes; N2, metastasis in 4 or more regional lymph nodes; Mx, distant metastasis cannot be assessed; M0, no distant metastasis; M1, distant metastasis.

cleaved from LHRH in the lysosomes and then accumulates in the nucleus. This uptake of AEZS-108 (AN-152) could be competitively inhibited by an excess of an LHRH agonist. By circumventing the MDR-1 mechanism AESZ-108 (AN-152) has been found to be active in cells resistant to conventional doxorubicin $(11,12)$. In cancer cell lines that do not express LHRH receptors, no intracellular accumulation of AEZS-108 (AN-152) could be detected (13).

In the present study, we have analyzed the expression of the LHRH receptor in specimens of human pancreatic cancers. Furthermore, we have investigated in vitro and in vivo whether the cytotoxic LHRH agonist AEZS-108 (AN-152) may be a suitable drug for an efficacious and less toxic therapy for human pancreatic cancers that express LHRH receptors.

\section{Materials and methods}

Cell lines and culture conditions. The pancreatic cancer cell lines MiaPaCa-2 and Panc-1 were obtained from the American Type Culture Collection (ATCC, Manassas, VA). MIAPaCa-2 cells were derived from epithelial tumor tissue of the pancreas obtained from a 65 -year-old Caucasian male. Panc-1 cells were derived from a ductal epithelioid carcinoma of the pancreas obtained from a 56-year-old Caucasian male. In order to guarantee the identity of the cell lines over the years, the cells were expanded after purchase and aliquots were stored in liquid nitrogen. Every half year a new frozen stock was opened and expanded to carry out the experiments. The cells were cultured at $37^{\circ} \mathrm{C}$ in a humidified atmosphere of $5 \% \mathrm{CO}_{2}$ in air as previously described (14-16).

Chemicals. The cytotoxic LHRH agonist AEZS-108 (AN-152), which consists of one molecule of doxorubicin14-0-hemiglutarate linked covalently to the $\varepsilon$-amino group of the D-Lys ${ }^{6}$ moiety of $\left[\mathrm{D}-\mathrm{Lys}^{6}\right] \mathrm{LHRH}$, was a gift from Aeterna Zentaris GmbH (Frankfurt, Germany). Doxorubicin was purchased from Sigma Chemical Company (Deisenhofen, Germany).

Inhibition of serum carboxylesterase. Carboxylesterase (CE) enzymes in fetal calf serum (FCS) can rapidly cleave AEZS-
108 (AN-152), releasing the cytotoxic radical doxorubicin. The organophosphate diisopropyl fluorophosphate (DFP) was used to inhibit CE activity in FCS. At a maximum concentration of $0.25 \mu \mathrm{g} / \mathrm{ml}$, no toxic effect to the cells was observed. To inhibit CE in the culture medium containing 10\% FCS, cells were treated for $1 \mathrm{~h}$ with DFP before addition of AEZS-108 (AN-152) or doxorubicin.

Human tissues. To analyze LHRH receptor expression in specimens of human pancreatic cancers we used human tissue arrays (US Biomax, Rockville, MD, USA) containing paraffinembedded human normal and malignant pancreatic tissues specimens, whose characteristics are outlined in Table I. Written, informed consent for the use of human tissues was obtained in accordance with the ethics guidelines that were effective at the time of collection and processing.

Animals. Female athymic (nude) mice (CD1 nu/nu), 6-8 weeks old on arrival, were obtained from Charles River (Sulzfeld, Germany). The mice were housed in sterile cages in a temperature-controlled room with 12-h light/12-h dark schedule and were fed autoclaved chow and water ad libitum. All experiments were performed according to the German ethics guidelines and the German laws for protection of animals.

Immunohistochemistry. The tissue array slides were deparaffinized and rehydrated. Antigens were retrieved by incubation with $0.01 \mathrm{M}$ citrate buffer $(\mathrm{pH} 6.0)$ in a microwave $(700 \mathrm{~W})$ for $5 \mathrm{~min}$. Endogenous peroxidase activity was quenched by treatment with 3\% hydrogen peroxide solution for $6 \mathrm{~min}$. After washing in PBS, the slides were treated with polyclonal rabbit anti-human LHRH receptor antiserum (17) in a $1: 10,000$ dilution in $1 \%$ BSA in $10 \mathrm{mM}$ Tris, $\mathrm{pH} 8.0$, $500 \mathrm{mM} \mathrm{NaCl}$ and $0.1 \%$ Tween-20 (TBST) for $1 \mathrm{~h}$ and, after being washed, were detected with the ready-to-use secondary horseradish peroxidase-conjugated anti-rabbit IgG antibody detection system according to the instructions of the supplier (Zymed Laboratories, San Francisco, CA, USA). Controls were performed by substitution of the primary antiserum with pre-immune serum of the same rabbit. Counterstaining was performed using Meyer's hematoxylin for $10 \mathrm{sec}$. The slides 

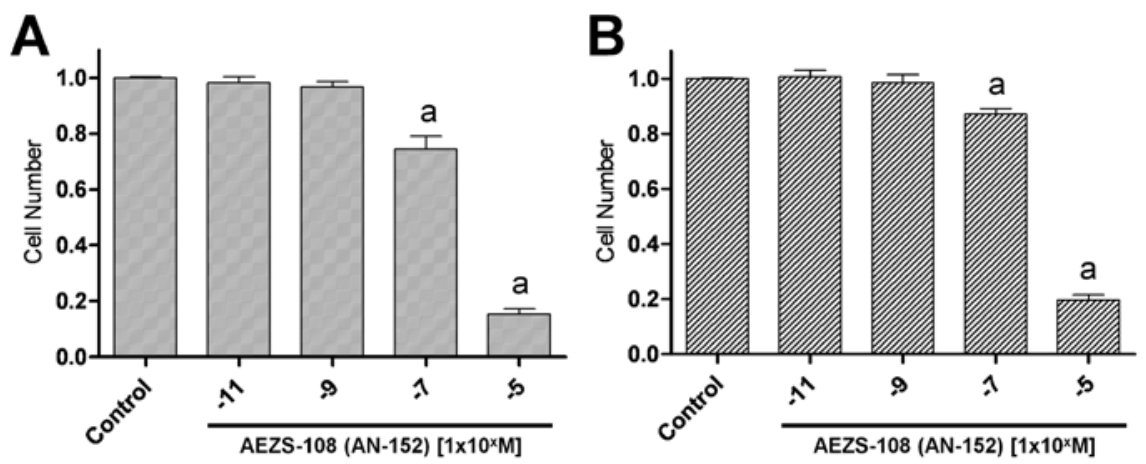

Figure 1. Dose-response experiments on cell proliferation of LHRH receptor-positive MiaPaCa-2 (A) and Panc-1 (B) human pancreatic cancer cells in vitro. Cells were incubated for 5 days without (control) or with increasing AEZS-108 (AN-152) concentrations. The cell number is given as a percentage of controls $(100 \%)$. Columns represent means \pm SEM of data obtained from three independent experiments in three different passages of the respective cell line. ${ }^{a} \mathrm{P}<0.001$ vs. control.

were then dehydrated, cleared, mounted with Permount and studied by light microscopy.

Proliferation assay. Cells (500/well) were plated into 96-well plates (Falcon, Heidelberg) in $100 \mu$ phenol redfree DMEM/5\% FCS (Biochrom, Berlin, Germany) $2 \mathrm{mM}$ glutamine, $50 \mathrm{U} / \mathrm{ml}$ penicillin/streptomycin, $2.5 \mu \mathrm{g} / \mathrm{ml}$ amphotericin B, and 1:100 non-essential amino acids. After cell attachment, $100 \mu \mathrm{l}$ medium or $100 \mu \mathrm{l}$ AEZS-108 (AN-152) solution at increasing final concentrations of $10^{-11}-10^{-5} \mathrm{M}$ was added to the wells in six replicates and incubated for 5 days at $37^{\circ} \mathrm{C}, 5 \% \mathrm{CO}_{2}$. Cell number was determined by a colorimetric assay using Alamar Blue (Biosource, Solingen, Germany). The optical density (OD) of the reduced dye was assessed at 570 vs. $630 \mathrm{~nm}$ after $4 \mathrm{~h}$ at $37^{\circ} \mathrm{C}$.

Mitochondrial membrane potential. For determination of AEZS-108 (AN-152)-induced loss of mitochondrial membrane potential, cells were treated without or with AEZS-108 (AN-152; $10^{-9}$ and $10^{-7} \mathrm{M}$ ) for $72 \mathrm{~h}$. After incubation, the cells were washed with PBS once and the mitochondrial membrane potential was detected using the JC-1 mitochondrial membrane potential detection kit according to the instructions of the manufacturer (Biotium, Hayward, CA, USA).

TUNEL assay. The terminal deoxynucleotidyl transferasemediated nick-end labeling (TUNEL) assay was used to monitor DNA fragmentation as a measure of apoptosis in tumor cells grown on slides after treatment with $10^{-7} \mathrm{M}$ AEZS-108 (AN-152) for 12-48 h. The cells were fixed using $4 \%$ paraformaldehyde in PBS at $4^{\circ} \mathrm{C}$ overnight and stained according to the recommendations of the manufacturer (DeadEnd Colorimetric TUNEL System, Promega, Mannheim, Germany). Counterstaining was performed using Meyer's hematoxylin for $10 \mathrm{sec}$.

In vivo studies. Tumors were initiated by subcutaneous injection of $1 \times 10^{7}$ cancer cells into the right flank. After 2 (MiaPaCa-2) or 3 (Panc-1) weeks all animals had developed solid tumors of about $80 \mathrm{~mm}^{3}$ and treatment was initiated. The in vivo experiments were conducted as follows: vehicle solution (control), $60 \mathrm{nmol}$ of doxorubicin or $60 \mathrm{nmol}$ of
AEZS-108 (AN-152) per mouse (5 mice per group) were injected intraperitoneally. The treatment was repeated every 3 days (days 0,3,6,9 and 12). Tumor volumes were measured on days $0,3,6,9,12$ and 15 of treatment. The mice were sacrificed after 15 days of treatment.

Statistical analysis. All experiments were repeated three times with different passages of the respective cell lines. The data were analyzed for significant differences by one-way analysis of variance followed by the Student-Newman-Keuls' test for comparison of individual groups, after a Bartlett test had shown that variances were homogeneous.

\section{Results}

LHRH receptor expression. Forty human pancreatic cancer specimns and 10 normal pancreatic tissues were analyzed for LHRH receptor expression (Table I). Twenty-seven human pancreatic cancer specimens (67.5\%) were LHRH receptornegative. Thirteen human pancreatic cancer specimens (32.5\%) showed LHRH receptor expression. None of the normal pancreas tissues showed LHRH receptor antigenicity.

Effects of AEZS-108 (AN-152) on cell proliferation. The cell number was quantified using the Alamar Blue colorimetric assay. Treatment of MiaPaCa-2 and Panc-1 human pancreatic cancer cells with increasing concentrations $\left(10^{-11}-10^{-5} \mathrm{M}\right)$ of AEZS-108 (AN-152) for 5 days resulted in a reduction of cell number (Fig. 1).

After treatment of MiaPaCa-2 human pancreatic cancer cells (Fig. 1A) with $10^{-11} \mathrm{M}$ and $10^{-9} \mathrm{M}$ of AEZS-108 (AN-152) no reduction of cell number was detectable. Treatment with $10^{-7} \mathrm{M}$ of AEZS-108 (AN-152) resulted in a decrease of the cell number to $74.45 \pm 5.65 \%$ of control $(\mathrm{P}<0.001)$. The effects were maximal at $10^{-5} \mathrm{M}$ concentrations of AEZS-108 (AN-152) and corresponded to a decrease of cell number to $15.39 \pm 1.89 \%$ of control $(\mathrm{P}<0.001)$.

After treatment of Panc-1 human pancreatic cancer cells (Fig. 1B) with $10^{-11}$ and $10^{-9} \mathrm{M}$ of AEZS-108 (AN-152) no reduction of cell number was detectable. Treatment with $10^{-7} \mathrm{M}$ of AEZS-108 (AN-152) resulted in a decrease of cell number to $87.00 \pm 2.04 \%$ of control $(\mathrm{P}<0.001)$. The effects were 

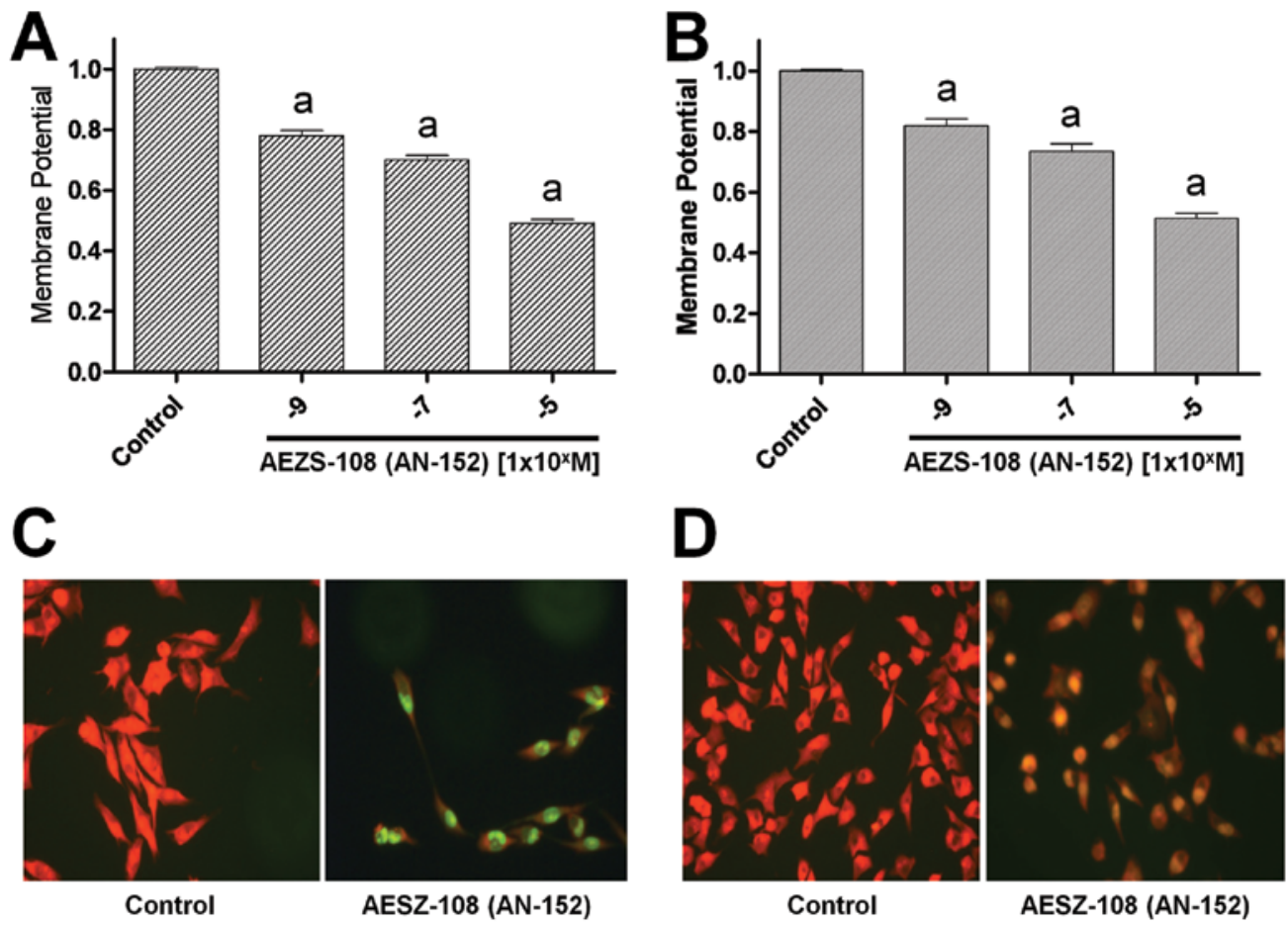

Figure 2. Effects of AEZS-108 (AN-152) treatment on induction of apoptosis in LHRH receptor-positive MiaPaCa-2 (A and C) and Panc-1 (B and D) human pancreatic cancer cells in vitro. (A and B) Percentage of mitochondrial membrane potential $(\Delta \Psi)$ after $72 \mathrm{~h}$ of treatment of MiaPaCa-2 (A) and Panc-1 (B) human pancreatic cancer cells without (control $=100 \%)$ or with AEZS-108 $\left(\mathrm{AN}-152 ; 10^{-9}-10^{-7} \mathrm{M}\right)$. Columns represent means \pm SEM of data obtained from four independent experiments in four different passages of the respective cell line. ${ }^{\mathrm{a}} \mathrm{P}<0.001$ vs. the control. (C and D) TUNEL assay showing DNA fragmentation as a measure of apoptosis in MiaPaCa-2 (C) and Panc-1 (D) human pancreatic cancer cells grown on slides after $36 \mathrm{~h}$ of treatment without (control) or with AEZS-108 (AN-152;10-7 M).

maximal at $10^{-5} \mathrm{M}$ concentrations of AEZS-108 (AN-152) and corresponded to a decrease of cell number to $19.77 \pm 1.78 \%$ of control $(\mathrm{P}<0.001)$.

Effects of AEZS-108 (AN-152) on mitochondrial membrane potential. Induction of apoptosis was analyzed by measurement of the loss of the mitochondrial membrane potential $(\Delta \Psi)$. Treatment of MiaPaCa-2 and Panc-1 human pancreatic cancer cells with increasing concentrations $\left(10^{-9}-10^{-5} \mathrm{M}\right)$ of AEZS-108 (AN-152) for $72 \mathrm{~h}$ resulted in a reduction of the $\Delta \Psi$ (Fig. 2A and B).

Treatment of MiaPaCa-2 human pancreatic cancer cells (Fig. 2A) with $10^{-9} \mathrm{M}$ of AEZS-108 (AN-152) resulted in a significant decrease of the $\Delta \Psi$ to $77.92 \pm 1.75 \%$ of the control $(\mathrm{P}<0.001)$. At $10^{-7} \mathrm{M}$ concentrations of AEZS-108 (AN-152) the decrease of the $\Delta \Psi$ was significant and corresponded to a decrease to $70.00 \pm 1.43 \%$ of the control $(\mathrm{P}<0.001)$. The effects were maximal at the $10^{-5} \mathrm{M}$ concentration of AEZS108 (AN-152) and corresponded to a decrease of the $\Delta \Psi$ to $49.17 \pm 1.18 \%$ of control $(\mathrm{P}<0.001)$.

The treatment of Panc-1 human pancreatic cancer cells (Fig. 2B) with $10^{-9} \mathrm{M}$ of AEZS-108 (AN-152) resulted in a significant decrease of the $\Delta \Psi$ to $81.94 \pm 2.27 \%$ of the control $(\mathrm{P}<0.001)$. At the $10^{-7} \mathrm{M}$ concentration of AEZS-108 (AN-152) the decrease of $\Delta \Psi$ was significant and corresponded to a decrease to $73.48 \pm 2.33 \%$ of the control $(\mathrm{P}<0.001)$. The effects were maximal at the $10^{-5} \mathrm{M}$ concentrations of AEZS108 (AN-152) and corresponded to a decrease of the $\Delta \Psi$ to $51.40 \pm 1.64 \%$ of control $(\mathrm{P}<0.001)$.
Effects of AEZS-108 (AN-152) on DNA fragmentation. The effects of AEZS-108 (AN-152) on induction of apoptotic cell death could be confirmed by visualization of DNA fragmentation (Fig. 2C and D). Treatment of MiaPaCa-2 human pancreatic cancer (Fig. 2C) and Panc-1 (Fig. 2D) human pancreatic cancer cells with $2 \times 10^{-7} \mathrm{M}$ of AEZS-108 (AN-152) resulted in a clear increase of apoptotic cells.

Effects of AEZS-108 (AN-152) on tumor growth in vivo. To show the proof-of-principle of an antitumor therapy using AEZS-108 (AN-152), nude mice bearing xenografted MiaPaCa-2 and Panc-1 human pancreatic tumors s.c. were treated with AEZS-108 (AN-152) (Fig. 3).

In vivo experiment 1 . In experiment 1 (Fig. 3A) female $\mathrm{CD} 1 \mathrm{nu} / \mathrm{nu}$ mice bearing MiaPaCa-2 human pancreatic tumors s.c. were treated without (control I) or with $60 \mathrm{nmol} / 20 \mathrm{~g}$ per injection of doxorubicin (control II) or with $60 \mathrm{nmol} / 20 \mathrm{~g}$ per injection of AEZS-108 (AN-152). The treatments were repeated every 3 days (5 injections total), and tumor volumes were measured every 3 days. The mice were sacrificed after 15 days of treatment. No side effects were observed. The increase of the tumor volume of the mice receiving therapy with AEZS108 (AN-152) was lower than with the control animals. Tumor growth was slightly inhibited starting on day 9 (4th measuring day) in comparison to the control group [287.8 $\pm 43.4 \%$ of the initial tumor volume $(=100 \%)]$ by treatment with AEZS-108 (AN-152) (194.1 $\pm 6.5 \%$ initial tumor volume, not significant vs. the control group) and also by treatment with doxorubicin $(255.7 \pm 16.9 \%$ initial tumor volume, not significant vs. the 

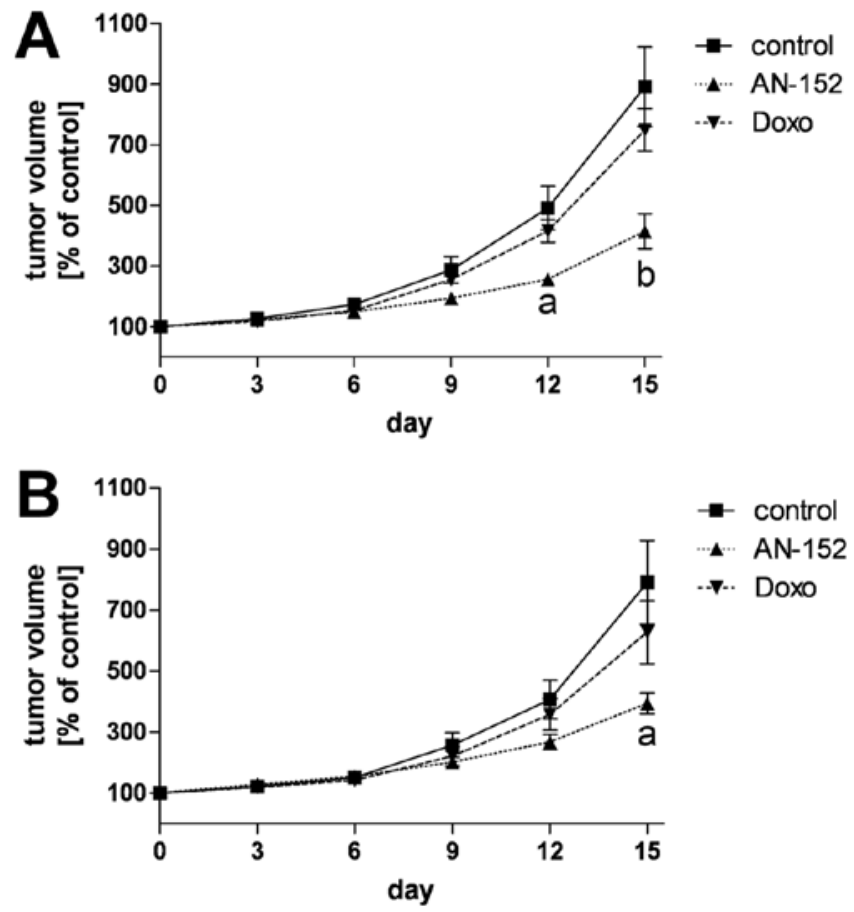

Figure 3. Tumor volume of MiaPaCa-2 (A) and Panc-1 (B) human pancreatic cancers xenografted into nude mice. The mice were treated without (vehicle solution, control) or with $60 \mathrm{nmol}$ of doxorubicin or with $60 \mathrm{nmol}$ of the cytotoxic LHRH agonist AEZS-108 (AN-152). Treatment was repeated every 3 days (days $0,3,6,9$ and 12). Tumor volumes were measured on day $0,3,6,9,12$ and 15 of treatment. The mice were sacrificed after 15 days of treatment. All experimental groups consisted of 5 animals. Vertical bars represent SEM. ${ }^{\mathrm{a}} \mathrm{P}<0.05$ vs. the control group and ${ }^{\mathrm{b}} \mathrm{P}<0.01$ vs. the control group.

control group). With progression of the experiment the antitumor effects of AEZS-108 (AN-152) continued to increase. After 12 days of treatment (5th measuring day), the differences became significant $(\mathrm{P}<0.05)$. After completion of therapy on day 15 (6th measuring day), the tumor volume of the mice that had received therapy with AEZS-108 (AN-152) was only one half of the tumor volume of the control animals [AEZS-108 (AN-152): $415.2 \pm 57.0 \%$ of the initial tumor volume, $\mathrm{P}<0.01 \mathrm{vs}$. the control group; control group: $891.2 \pm 131.2 \%$ of the initial tumor volume]. Treatment with doxorubicin $(748.8 \pm 69.9 \%$ of initial tumor volume on day 15 of treatment) showed minor but not significant differences to the control group.

In vivo experiment 2. In experiment 2 (Fig. 3B) female CD1 nu/nu mice bearing Panc-1 human pancreatic tumors s.c. were treated without (control I) or with $60 \mathrm{nmol} / 20 \mathrm{~g}$ per injection of doxorubicin (control II) or with $60 \mathrm{nmol} / 20 \mathrm{~g}$ per injection of AEZS-108 (AN-152). The treatments were repeated every 3 days (5 injections total), and tumor volumes were measured every 3 days. The mice were sacrificed after 15 days of treatment. No side effects were observed. The increase of the tumor volume of the mice receiving therapy with AEZS-108 (AN-152) was lower than with the control animals. Tumor growth was slightly inhibited by day 9 (4th measuring day) in comparison to the control group $[257.5 \pm 41.1 \%$ of the initial tumor volume $(=100 \%)]$ by treatment with AEZS-108 (AN-152) (201.5 $\pm 11.9 \%$ initial tumor volume, not significant vs. the control group) and also by treatment with doxorubicin $(220.3 \pm 30.9 \%$ initial tumor volume, not significant vs. the control group). Upon further treatment antitumor effects of AEZS-108 (AN-152) increased. After 15 days of treatment (6th measuring day), the differences became significant $(\mathrm{P}<0.05)$. The tumor volume of the mice that had received therapy with AEZS-108 (AN-152) was one half of the tumor volume of the control animals [control group, $790.5 \pm 137.3 \%$ of the initial tumor volume; AEZS-108 (AN-152), 393.7 $\pm 34.2 \%$ of the initial tumor volume, $\mathrm{P}<0.05$ vs. control group]. Treatment with doxorubicin $(627.0 \pm 103.5 \%$ of the initial tumor volume on day 15 of treatment) showed minor but not significant differences to the control group.

\section{Discussion}

Previous studies have shown that AEZS-108 (AN-152) induces apoptotic cell death in LHRH receptor-positive human endometrial, ovarian and breast cancer cells in vitro and in vivo $(13,18,19)$. In addition, we could demonstrate that AEZS-108 (AN-152)-induced apoptosis in human endometrial, ovarian and breast cancer cell lines is independent of the multidrug resistance-1 (MDR-1) system $(11,12)$. Because of the LHRH receptor-mediated entry of AEZS-108 (AN-152) into the cancer cells, AEZS-108 (AN-152) may overcome chemoresistance, which is a major drawback of systemic therapy of these malignancies by anthracyclines and other chemotherapeutic agents $(11,12)$. The poor prognosis of pancreatic cancer is believed to be partly due to primary or secondary chemoresistance of specific subgroups of pancreatic cancer cells, namely those with an epithelial-mesenchymal transition (EMT) phenotype and cancer stem cells (20).

Some reports have shown that pancreatic cancers express LHRH receptors (6-8). Therefore, we considered that a therapy using LHRH receptors as a target may be applicable for LHRH receptor-positive pancreatic cancers. First, we analyzed LHRH receptor expression in tumor specimens of human pancreatic cancers using immunohistochemistry. We could show that 13 of 40 human pancreatic cancers $(32.5 \%)$ expressed LHRH receptors. None of the normal pancreatic tissues $(\mathrm{n}=10)$ showed LHRH receptor expression. Friess et al detected LHRH binding sites in $57 \%$ of patients $(n=23)$ with ductal pancreatic cancer and in 1 of 11 normal pancreatic tissues $(9.1 \%)$ (6). These discrepancies may be due to differences in the techniques used (immunohistochemistry of paraffin embedded tissues vs. ${ }^{125} \mathrm{I}$-[t-butyl-D-serin $\left.{ }^{6}\right] \mathrm{LHRH}$ binding assay of homogenized tissues). Since most organs including the normal pancreas and hematopoietic stem cells do not express LHRH receptors (19), these receptors could be used as a target site for well tolerable therapies.

Pancreatic adenocarcinoma, the most common type of pancreatic cancer, is the most aggressive of all cancers. Pancreatic cancer spreads rapidly and is seldom detected in its early stages $(1,2)$. By the time pancreatic cancer is diagnosed, most patients have already developed distant metastases. For patients with advanced cancers, the overall survival rate of all stages is less than $1 \%$ at 5 years with most patients dying within 1 year (21-24). Because pancreatic cancer is also relatively resistant to medical treatment, the therapeutic options are very limited. Treatment with the cytotoxic LHRH agonist AEZS-108 (AN-152) could be a new option for the therapy 
of pancreatic cancer as approximately $29 \%$ of these tumors $(n=40)$ may express LHRH receptors.

In the present study, we could demonstrate that treatment of LHRH receptor-positive MiaPaCa-2 and Panc-1 human pancreatic cancer cells with the cytotoxic LHRH agonist AEZS-108 (AN-152) in vitro resulted in apoptotic cell death via loss of mitochondrial membrane potential. In addition, we could show the proof-of-principle of an antitumor therapy using AEZS-108 (AN-152) in vivo in nude mice bearing s.c. xenografts of human LHRH receptor-positive pancreatic cancers. Nude mice bearing MiaPaCa-2 or Panc-1 human pancreatic cancers were treated without or with AEZS-108 (AN-152) or with doxorubicin. The tumor growth of the mice receiving therapy with AEZS-108 (AN-152) was significantly reduced. Toxic side effects were not observed. Equimolar doses of doxorubicin were nearly ineffective in inducing apoptosis in LHRH receptor-positive human pancreatic tumors and in reducing their growth in vivo. Our findings could be the basis for further evaluation in clinical trials. In a current phase II study, AEZS-108 (AN-152) was found to be active and welltolerated in patients with heavily pretreated platinum- and taxane-resistant LHRH receptor-positive ovarian cancer (25). Patients with any stage of pancreatic cancer can appropriately be considered candidates for clinical trials because of the poor response to chemotherapy, radiation therapy, and surgery as conventionally used.

In conclusion, we were able to show that about $29 \%$ of human pancreatic cancers express LHRH receptors and that AEZS-108 (AN-152) induces apoptotic cell death in LHRH receptor-positive MiaPaCa-2 and Panc-1 human pancreatic cancer cells in vitro and in vivo. Apoptosis induced by AEZS108 (AN-152) is mediated through the intrinsic apoptotic pathway via loss of mitochondrial membrane potential.

Thus, the cytotoxic LHRH agonist AEZS-108 (AN-152) seems to be a suitable drug for targeted chemotherapy for LHRH receptor-positive human pancreatic cancers.

\section{Acknowledgements}

This study was supported by a grant of the Deutsche Krebshilfe, Dr Mildred Scheel Stiftung. We thank Aeterna Zentaris GmbH (Frankfurt, Germany) for the gift of the cytotoxic LHRH agonist AEZS-108 (AN-152) and Sonja Blume, Renate Dietrich, Matthias Läsche and Hildtrud Schulz for excellent technical assistance.

\section{References}

1. Wong HH and Lemoine NR: Pancreatic cancer: molecular pathogenesis and new therapeutic targets. Nat Rev Gastroenterol Hepatol 6: 412-422, 2009.

2. Baumgart M, Heinmoller E, Horstmann O, Becker $\mathrm{H}$ and Ghadimi BM: The genetic basis of sporadic pancreatic cancer. Cell Oncol 27: 3-13, 2005.

3. Tanase CP, Neagu M, Albulescu R and Hinescu ME: Advances in pancreatic cancer detection. Adv Clin Chem 51: 145-180, 2010.

4. Kornmann M, Beger HG and Link KH: Chemosensitivity testing and test-directed chemotherapy in human pancreatic cancer. Recent Results Cancer Res 161: 180-195, 2003.
5. Zalatnai A and Molnar J: Review. Molecular background of chemoresistance in pancreatic cancer. In Vivo 21: 339-347, 2007.

6. Friess H, Buchler $M$, Kiesel L, Kruger $M$ and Beger HG: $\mathrm{LH}-\mathrm{RH}$ receptors in the human pancreas. Basis for antihormonal treatment in ductal carcinoma of the pancreas. Int J Pancreatol 10: 151-159, 1991.

7. Schally AV and Nagy A: Chemotherapy targeted to cancers through tumoral hormone receptors. Trends Endocrinol Metab 15: 300-310, 2004

8. Schally AV, Engel JB, Emons G, Block NL and Pinski J: Use of analogs of peptide hormones conjugated to cytotoxic radicals for chemotherapy targeted to receptors on tumors. Curr Drug Deliv 8: 11-25, 2011.

9. Gründker C, Günthert AR, Westphalen S and Emons G: Biology of the gonadotropin-releasing hormone system in gynecological cancers. Eur J Endocrinol 146: 1-14, 2002.

10. Schally AV and Nagy A: Cancer chemotherapy based on targeting of cytotoxic peptide conjugates to their receptors on tumors. Eur J Endocrinol 141: 1-14, 1999.

11. Günthert AR, Gründker C, Bongertz T, Nagy A, Schally AV and Emons G: Induction of apoptosis by AN-152, a cytotoxic analog of luteinizing hormone-releasing hormone (LHRH), in LHRH-R positive human breast cancer cells is independent of multidrug resistance-1 (MDR-1) system. Breast Cancer Res Treat 87: 255-264, 2004.

12. Günthert AR, Gründker C, Bongertz T, et al: Internalization of cytotoxic analog $\mathrm{AN}-152$ of luteinizing hormone-releasing hormone induces apoptosis in human endometrial and ovarian cancer cell lines independent of multidrug resistance-1 (MDR-1) system. Am J Obstet Gynecol 191: 1164-1172, 2004.

13. Westphalen S, Kotulla G, Kaiser F, et al: Receptor mediated antiproliferative effects of the cytotoxic LHRH agonist AN-152 in human ovarian and endometrial cancer cell lines. Int J Oncol 17: 1063-1069, 2000

14. Emons G, Ortmann O, Becker M, et al: High affinity binding and direct antiproliferative effects of LHRH analogues in human ovarian cancer cell lines. Cancer Res 53: 5439-5446, 1993.

15. Emons G, Schröder B, Ortmann O, Westphalen S, Schulz KD and Schally AV: High affinity binding and direct antiproliferative effects of luteinizing hormone-releasing hormone analogs in human endometrial cancer cell lines. J Clin Endocrinol Metab 77: 1458-1464, 1993.

16. Irmer G, Bürger C, Müller R, et al: Expression of the messenger RNAs for luteinizing hormone-releasing hormone (LHRH) and its receptor in human ovarian epithelial carcinoma. Cancer Res 55: 817-822, 1995.

17. Gründker C, Schlotawa L, Viereck V, et al: Antiproliferative effects of the GnRH antagonist cetrorelix and of GnRH-II on human endometrial and ovarian cancer cells are not mediated through the GnRH type I receptor. Eur J Endocrinol 151: 141-149, 2004.

18. Gründker C: Cytotoxic luteinizing hormone-releasing hormone conjugates and their use in gynecological cancer therapy. Eur J Endocrinol 143: 569-572, 2000.

19. Gründker C, Völker P, Griesinger F, et al: Antitumor effects of the cytotoxic luteinizing hormone-releasing hormone analog AN-152 on human endometrial and ovarian cancers xenografted into nude mice. Am J Obstet Gynecol 187: 528-537, 2002.

20. Wang Z, Li Y, Ahmad A, et al: Pancreatic cancer: understanding and overcoming chemoresistance. Nat Rev Gastroenterol Hepatol 8: 27-33, 2010.

21. Lillemoe KD: Current management of pancreatic carcinoma. Ann Surg 221: 133-148, 1995.

22. Yeo CJ: Pancreatic cancer: 1998 update. J Am Coll Surg 187: 429-442, 1998.

23. Nitecki SS, Sarr MG, Colby TV and van Heerden JA: Long-term survival after resection for ductal adenocarcinoma of the pancreas. Is it really improving? Ann Surg 221: 59-66, 1995.

24. Conlon KC, Klimstra DS and Brennan MF: Long-term survival after curative resection for pancreatic ductal adenocarcinoma. Clinicopathologic analysis of 5-year survivors. Ann Surg 223: 273-279, 1996.

25. Emons G, Tomov S, Harter P, et al: Phase II study of AEZS-108 (AN-152), a targeted cytotoxic LHRH analog, in patients with LHRH receptor-positive platinum resistant ovarian cancer. J Clin Oncol 28 (Suppl 15): 5035, 2010. 